\title{
First molecular identification of mosquito vectors of Dirofilaria immitis in continental Portugal
}

\author{
Cátia Alexandra Costa Ferreira ${ }^{1 \dagger}$, Verónica de Pinho Mixão ${ }^{1 \dagger}$, Maria Teresa Lourenço Marques Novo', \\ Maria Manuela Palmeiro Calado', Luzia Augusta Pires Gonçalves ${ }^{3,4}$, Silvana Maria Duarte Belo ${ }^{1}$ \\ and António Paulo Gouveia de Almeida ${ }^{1,2^{*}}$
}

\begin{abstract}
Background: Canine dirofilariasis due to Dirofilaria immitis is known to be endemic in continental Portugal. However, information about the transmitting mosquito species is still scarce, with only Culex theileri identified to date, albeit with L1-2, through dissection. This study was carried out to investigate the potential vectors of Dirofilaria spp. in continental Portugal.

Methods: Mosquitoes were collected in three distinct seasons (Summer, Autumn and Spring), 2011-2013, in three districts. CDC traps and indoor resting collections were carried out in the vicinity of kennels. Mosquitoes were kept under controlled conditions for 7 days to allow the development of larval stages of Dirofilaria spp.. DNA extraction was performed separately for both head+thorax and abdomen in order to differentiate infective and infected specimens, respectively, in pools, grouped according to the species and collection site (1-40 specimen parts/pool), and examined by PCR using pan-filarial specific primers. Mosquito densities were compared using non-parametric tests. Dirofilaria development units (DDU) were estimated.

Results: In total, 9156 female mosquitoes, from 11 different species, were captured. Mosquito densities varied among the 3 districts, according to capture method, and were generally higher in the second year of collections. From 5866 specimens screened by PCR, 23 head+thorax and 41 abdomens pools, corresponding to 54 mosquitoes were found positive for D. immitis DNA. These belonged to 5 species: Culex (Cux) theileri (estimated rate of infection $(E R I)=0.71 \%), C X$. (CUX) pipiens f. pipiens and f. molestus (ERI=0.5\%), Anopheles (Ano) maculipennis s.l. (ERI=3.12\%), including An. (Ano) atroparvus, Aedes (Och) caspius (ERI=3.73\%) and Ae. (Och) detritus s.l. (ERI=4.39\%). All but $C X$. pipiens, had at least one infective specimen. No D. repens infected specimens were found. Infection rates were: 3.21\% in Coimbra, 1.22\% in Setúbal and 0.54\% in Santarém. DDU were at least 117/year in the study period.

Conclusions: Culex theileri, Cx. pipiens, An. maculipennis s.l. An. atroparvus, Ae.caspius and Ae. detritus s.l. were identified as potential vectors of D. immitis in three districts of Portugal, from Spring to Autumn, in 5 of the 6 collection dates in 2011-2013. Implications for transmission, in the context of climate changes, and need for prophylactic measures, are discussed.
\end{abstract}

Keywords: Dirofilaria, Mosquitoes, Vectors, Portugal, DDU, Cx. theileri, Cx. pipiens, An. maculippenis s.l, Ae. caspius, Ae. detritus s.l

\footnotetext{
*Correspondence: palmeida@ihmt.unl.pt

${ }^{\dagger}$ Equal contributors

'Medical Parasitology Unit, Medical Parasitology \& Microbiology Unit-UPMM,

Instituto de Higiene e Medicina Tropical, Universidade Nova de Lisboa, Rua

da Junqueira 100, 1349-008 Lisboa, Portugal

${ }^{2}$ Zoonosis Research Unit, Faculty of Health Sciences, University of Pretoria,

Pretoria, South Africa

Full list of author information is available at the end of the article
}

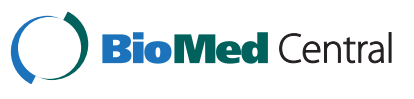

(c) 2015 Costa Ferreira et al.; licensee BioMed Central. This is an Open Access article distributed under the terms of the Creative Commons Attribution License (http://creativecommons.org/licenses/by/4.0) which permits unrestricted use, distribution, and reproduction in any medium, provided the original work is properly credited. The Creative Commons Public Domain Dedication waiver (http://creativecommons.org/publicdomain/zero/1.0/) applies to the data made available in this article, unless otherwise stated. 


\section{Background}

Dirofilariasis is a mosquito-borne cosmopolitan metazoonotic disease caused by different species of the nematode genus Dirofilaria (Spirurida: Onchocercidae) [1], namely Dirofilaria immitis (Leidy, 1856), canine or dog heartworm, and Dirofilaria repens Railliet\& Henry, 1911.

Although the natural hosts of Dirofilaria spp. are dogs and wild members of the genus Canis, canine dirofilariasis (CD) infections may occur in a variety of species, including cats, other wild mammals and humans $[2,3]$. Previously human dirofilariasis (HD) was considered a rare disease, but a recent increase in the number of $\mathrm{CD}$ and HD cases, particularly after 2000, has resulted in it being classified as an emerging zoonosis $[4,5]$. Recent accounts of autochthonous cases of CD have stemmed from Slovakia [6], Hungary [7], Poland [8], and of HD from Hungary [9], Poland [10], Ukraine [11], and seroreactivity prevalences ranging from 5\%-27\% amongst humans, have been recorded in Serbia [12].

Dirofilaria spp. are transmitted by several mosquito species belonging to a wide range of genera in different parts of the world, such as Culex, Aedes and Anopheles [5]. Vectors ingest microfilariae, while feeding on an infected host, which then cross the midgut wall and migrate to the Malpighian tubules (MT) where they develop from first to third stage larvae. Later, the L3 (infective larvae) migrate to the proboscis through which they slide while the mosquito is feeding on another host, becoming sexually mature within six months in the main pulmonary arteries and right ventricle [1]. Transmission of dirofilariasis is dependent upon the presence of sufficient numbers of infected and microfilaremic dogs, susceptible mosquitoes, and a suitable climate to allow extrinsic incubation of the parasite in the mosquito vector $[13,14]$. Environmental factors, namely climatic and ecological, may affect the life cycle parameters of both the mosquito vector and filarial parasites.

Various studies in European countries and neighbouring areas have reported several species of mosquitoes as natural vectors of $D$. immitis such as Culex (Culex) pipiens in Spain [15], Italy [16,17], and [18], Aedes (Ochlerotatus) vexans in Turkey [18], Cx. (Cux) theileri on Madeira and Canary Islands [19,20], Cx. theileri and Anopheles (Anopheles) maculipennis s.l. in Iran [21] and Aedes (Stegomyia) albopictus, An. maculipennis s.l. and Coquillettidia (Coquillettidia) richiardii in Italy [16,22].

Canine dirofilariasis due to $D$. immitis is known to be endemic in continental Portugal. In 2009-2010 the overall sero-prevalence in Northern and Central Portugal was $2.1 \%$ for CD [23]. A recent survey, 2011-2013, in three districts of Centre-South, has revealed an overall parasitological prevalence rate of $15.1 \%$, the highest in Setúbal (24.8\%), followed by Coimbra (13.8\%) and Santarém (13.2\%) [24].
Despite these high prevalences, information about the transmitting mosquito species was still scarce in continental Portugal, with $C x$. theileri as the only likely vector of Dirofilaria spp. [25]. In addition, high densities of mosquito populations, namely $C x$. theileri, $C x$. pipiens s.l. An. maculipennis s.l. and Ae.caspius, were recorded in the above mentioned areas [26]. Hence, the purpose of this study was to identify potential vectors of Dirofilaria spp. by using a polymerase chain reaction (PCR) with species specific primers on mosquito populations from those three districts of continental Portugal, Coimbra, Santarém and Setúbal, collected in the vicinity of kennels being surveyed for $C D$, in a multidisciplinary project, for a period of two consecutive years.

\section{Methods}

\section{Sampling area}

The research was concentrated on three districts of Portugal: Coimbra (Centre), Santarém, and Setúbal (Centre-South), located at the basins of rivers Mondego, Tejo and Sado, respectively (Figure 1). These districts present different prevalences of dog infections, ecological and overall soil use, although they have in common the presence of the main rice culture areas in the country. The number of localities surveyed in each district was, Coimbra- four, Santarém- five, and Setúbal- four.

Daily temperature data of 2011, 2012 and 2013 from stations operated close to the collections sites, were obtained from "Instituto Português do Mar e da Atmosfera" [27]. Average minimum and maximum monthly temperatures and rainfall values, for the study period are depicted in Table 1.

\section{Mosquito collection and identification}

Mosquitoes were collected by CDC light traps baited with dry ice, between 5.00 p.m. and 7.00 a.m., for active adult mosquitoes and with mechanical aspirators in the early morning targeting indoor resting mosquitoes (IR). Collections were carried out in kennels (whose identities are confidential) or their vicinity, but also in suburban or rural areas in those districts. Collections were carried out from 2011 to 2013, in July, October-November and April-May corresponding to Summer, Autumn and Spring seasons. Mosquitoes were kept in the insectary under controlled conditions of temperature and humidity $\left(25 \pm 2^{\circ} \mathrm{C}, 70 \pm 5 \% \mathrm{RH}\right)$, a photoperiod of $12 \mathrm{~h}: 12 \mathrm{~h}$ (light:dark) and fed 10\% sucrose solution, for 7 days to allow bloodmeal digestion and eventual parasite development to the infective L3 stage [1], as done in other studies [22]. After this period, those specimens still alive were frozen until species identification was carried out according to the keys of Ribeiro \& Ramos [28]. Mosquitoes that were dead at time of trap collection, or that 


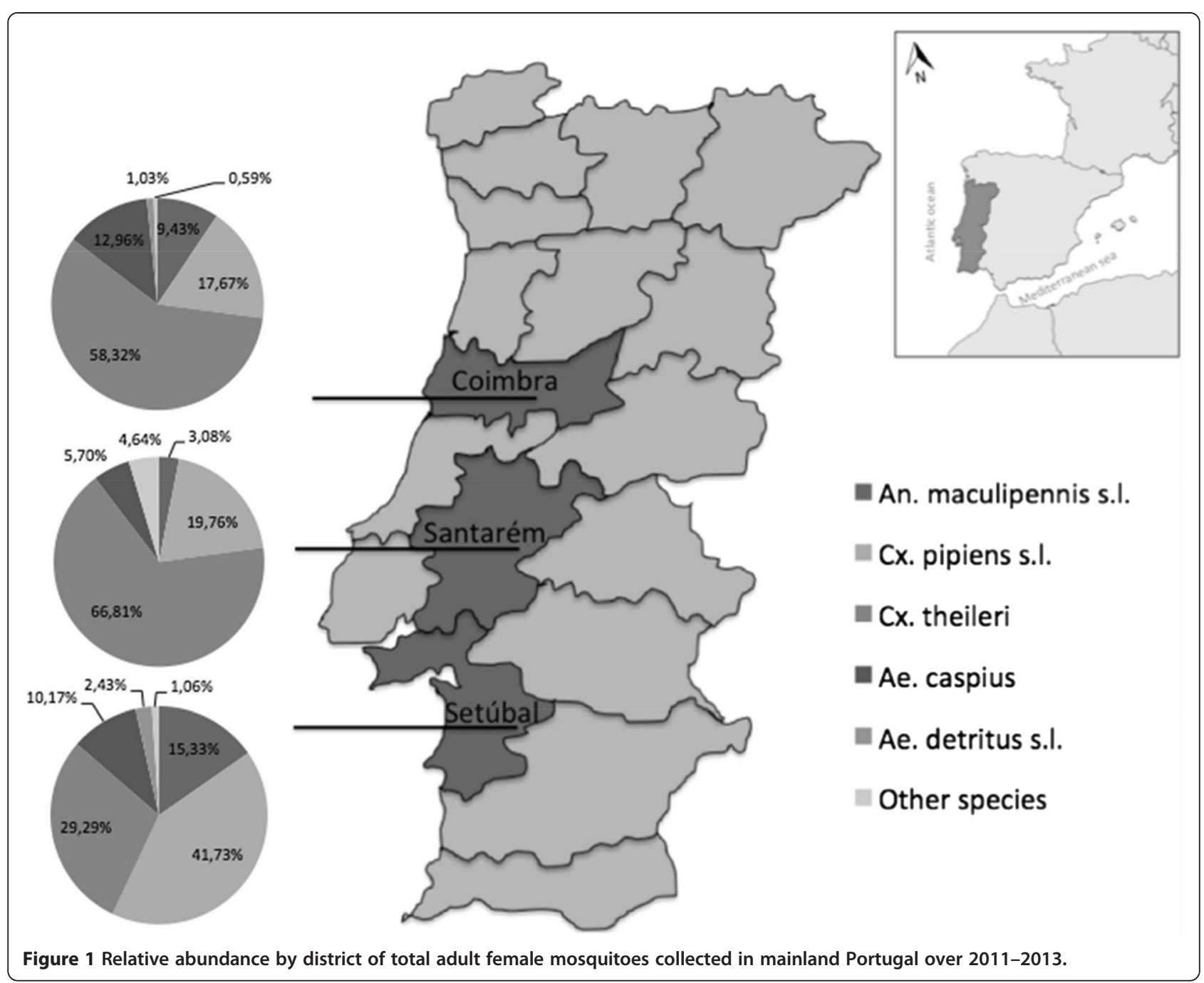

died during the following seven day period, were also frozen, identified and screened for filarial infection.

\section{Set of biological material for PCR analysis}

Mosquito females were dissected into head+thorax and abdomen to discriminate between Dirofilaria spp. infective/infected status, respectively [29]. Specimens belonging to the same collection, species, in identical gonotrophic stage, that had been the same number of days in the insectary, were joined in pools of these body parts, ranging from 1 to 40 specimen parts. Specimens of $C x$. pipiens s.l. were individually analyzed, due to the sympatric existence of the two biological forms, pipiens and molestus of the sensu strictu species, in Portugal [30].

\section{DNA isolation}

Genomic DNA was extracted from samples using the CTAB (Cetyltrimethylammonium bromide) method, adapted from Stothard et al. [31] by grinding the mosquito samples in a buffer (100 mMTris, $1.4 \mathrm{M} \mathrm{NaCl}$, 20 mM EDTA, 2\% Hexadecyltrimethylammonium bromide (CTAB), $0.2 \%$ mercaptoethanol) and incubating with

Table 1 Average minimum and maximum, monthly temperatures and rainfall values, standard deviations, and respective months [27]

\begin{tabular}{lll}
\hline $\mathbf{2 0 1 1 - 2 0 1 3}$ & Coimbra & Santarém \\
\hline Minimum average temperature & $9.3 \pm 2.6^{\circ} \mathrm{C}($ Feb) & $11.7 \pm 2.0^{\circ} \mathrm{C}(\mathrm{Jan})$ \\
Maximum average temperature & $20.4 \pm 1.8^{\circ} \mathrm{C}(\mathrm{Aug})$ & $24.8 \pm 2.4^{\circ} \mathrm{C}(\mathrm{Aug})$ \\
Maximum average rainfall & $1.83 \pm 5.91 \mathrm{~mm}(\mathrm{Oct})$ & $1.65 \pm 4.79 \mathrm{~mm}(\mathrm{Mar})$ \\
Minimum average rainfall & $0.02 \pm 0.12 \mathrm{~mm}(\mathrm{Jul})$ & $0 \pm 0 \mathrm{~mm}(\mathrm{Jul} / \mathrm{Aug})$ \\
\hline
\end{tabular}


proteinase $\mathrm{K}$ (Bioline) at $55^{\circ} \mathrm{C}$ for $90 \mathrm{~min}$ with agitation. Phenol/chloroform/isoamyl alcohol was used for further DNA purification. DNA was ethanol precipitated and pellet was suspended in TE buffer ( $\mathrm{pH}$ 7.0).

\section{DNA amplification}

DNA from head+thorax and abdomen samples were analyzed by panfilarial primers DIDR-F1 (5'-AGT GCG AAT TGC AGA CGC ATT GAG-3') and DIDR-R1 (5'AGC GGG TAA TCA CGA CTG AGT TGA-3'), described by Rishniw et al. [32]. PCR was performed in $25 \mu \mathrm{l}$ reaction mixture containing a final concentration of 1 X GreenGoTaq ${ }^{\circ}$ Flexi Buffer(Promega), $6 \mathrm{mM}$ $\mathrm{MgCl}_{2}$ (Promega), $0.012 \mathrm{mM}$ of each dNTP (Promega), $0.4 \mathrm{pM}$ of each primer, $0.1 \mathrm{U} / \mu \mathrm{l}$ of GoTaq ${ }^{\circ}$ DNA Polymerase (Promega) and $1.6 \mathrm{ng} / \mu \mathrm{l}$ of template DNA. Deionized water was added to complete the final volume. The thermal cycler was set at $94^{\circ} \mathrm{C}$ for $2 \mathrm{~min}$ and then 32 cycles, each of denaturation for $30 \mathrm{~s}$ at $94^{\circ} \mathrm{C}$, annealing for $30 \mathrm{~s}$ at $60^{\circ} \mathrm{C}$, extension for $30 \mathrm{~s}$ at $72^{\circ} \mathrm{C}$ and a final extension for $7 \mathrm{~min}$ at $72^{\circ} \mathrm{C}$.

Biological forms of $C x$. pipiens s.l. samples that were positive for Dirofilaria spp. were diagnosed with specific primers pipCQ11R (5'-CAT GTT GAG CTT CGG TGA A-3'), form pipiens (200 bp), and molCQ11R (5'-CCC TCC AGT AAG GTA TCA AC-3'), form molestus (250 bp), and universal primer CQ11F2 (5'-GAT CCT AGC AAG CGA GAA C-3') for microssatellite locus CQ11, as described by Bahnck \& Fonseca, 2006 [33]. Positive controls from homozygous $C x$. pipiens f. pipiens and $C x$. pipiens f. molestus were used and deionized water was used as negative control.

In order to confirm that a product of $250 \mathrm{pb}$ in the last mentioned PCR belongs to $C x$. pipiens $\mathrm{f}$. molestus and not to $C x$. quinquefasciatus, these members of the Culex pipiens complex were differentiated according to polymorphisms in the intron-2 of the acetylcholinesterase-2 (ace-2) gene [34]. Specific primers to detect Cx. pipiens s.s. $(610 \mathrm{pb})$ and $C x$. quinquefasciatus $(274 \mathrm{pb})$ were used, namely, ACEpip (5'-GGA AAC AAC GAC GTA TGT ACT-3') and ACEquin (5'-CCT TCT TGA ATG GCT GTG GCA-3') and universal primer B1246s (5'TGG AGC TCC TCT TCA CGG-3'), as described by Smith \& Fonseca, 2004 [34]. Genomic DNA from homozygous $C x$. pipiens $\mathrm{f}$. pipiens and $C x$. quinquefasciatus and deionized water were used as positive and negative controls.

For all PCR reactions described above, amplified products were separated on $1.5 \%$ agarose gel eletrophoresis and observed under UV light.

\section{Sensitivity test of PCR}

In order to determine the sensitivity of the PCR assay, two procedures were devised. Assays were carried out with DNA extracted from $C x$. theileri female mosquitoes from IHMT colony, also separated into head+thorax and abdomen: i) to determine the minimum amount of parasite DNA that would be detected by the PCR assay, definite amounts of parasite DNA (10 ng, $5 \mathrm{ng}, 1 \mathrm{ng}$, $0.1 \mathrm{ng}, 10 \mathrm{pg}$ and $1 \mathrm{pg}$ ) were mixed with $80 \mathrm{ng}$ of mosquito DNA, and PCR reaction was performed in same conditions as described above. This showed that it was able to detect up to $10 \mathrm{pg}$ of parasite DNA in $80 \mathrm{ng}$ of mosquito DNA, either from head+thorax or abdomen; ii) it was also determined the sensitivity cut-off of detecting an infected mosquito in a pool of 40 mosquitoes. After the first individual specimen of $C x$. theileri positive for $D$. immitis was detected, a sample from this pool with $80 \mathrm{ng} / \mu \mathrm{l}$ of total DNA, was diluted in uninfected $C x$. theileri DNA at the same $80 \mathrm{ng} / \mu \mathrm{l}$ concentration. The test was started with $4 \mu \mathrm{l}$ of the positive sample joined with $36 \mu \mathrm{l}$ of uninfected mosquito DNA, i.e. 4:40, followed by 3:40, 2:40, 1:40, and 0.1:40. Parasite DNA was detected until 1:40 dilution, either for head+thorax or abdomen pools, corresponding to one single positive mosquito in a pool of 40 mosquitoes.

\section{DNA sequencing and analysis}

Products from the first PCR described (panfilarial) were purified by QIAquick PCR Purification Kit (Qiagen) and sequenced by Macrogen. Sequences were edited and aligned using BioEdit [35], and compared to other similar sequences available in Genbank, as identified through BLAST [36].

\section{Calculation of the infection rate of mosquitoes}

The infection rate of mosquitoes were estimated by: i) Minimum infection rate (MIR), i.e. the number of positive mosquito pools/total number of mosquitoes in pools tested $\times 1000$, and ii) Estimated Rate of Infection (ERI) which is adjusted for pooled samples, by the formula: ERI $=1-(1-\mathrm{x} / \mathrm{m}) 1 / \mathrm{k}$ where $\mathrm{x}$ is the number of positive pools; $\mathrm{m}$ the number of examined pools and $\mathrm{k}$ the average number of specimens in each pool [37].

\section{Ethical considerations}

The study was approved by the Commission on Ethics of the Instituto de Higiene e Medicina Tropical, Universidade Nova de Lisboa with reference 21-2013-TM, and all procedures were performed according to national and European legislation.

\section{Mosquito data and statistical analysis}

Mosquito densities are presented as the number of mosquitoes captured per trap-night for CDC collections, or as the number of mosquitoes collected per collectorhour for IR collections. The arithmetic mean and the standard deviation were calculated for densities per 
district for all collections of each type, and date. However, the median and interquartile interval (Q1-Q3) revealed to be most appropriate for this data.

Statistical analysis was carried out using the SPSS package version 20.0 for Windows [38]. KolmogorovSmirnov (Lilliefors modification) and Shapiro-Wilk tests were used to analyse data for normality, while Levene's test was used to test for homogeneity of variance. Due to the lack of normality of the data, large standard deviations and lack of homogeneity of variance, non-parametric tests were used to analyse mosquito densities [39]. MannWhitney (MW) and Kruskal-Wallis (KW) tests were used for comparing, respectively, mosquito densities between the two years, and mosquito densities among the three districts. In the latter case, whenever significant differences were found, multiple comparisons were performed using the Dunn-Bonferroni (DB) pairwise comparisons.

Differences in mosquito rates of infection among species and locations were compared using Chi-squared test and Fisher's exact test.

\section{Estimation of Dirofilaria development units (DDU)}

In order to determine the hypothetical period in which there was risk of heartworm disease transmission in the surveyed areas, Dirofilaria Development Units (DDU) were calculated. For each day in which the average temperature was $>14^{\circ} \mathrm{C}$, temperature at which there is no extrinsic development of the parasite, the difference between the average temperature and $14^{\circ} \mathrm{C}$ was calculated (i.e. for Tmean $\geq 15$, DDU=Tmean-14) [40]. The sum of DDUs in the 30 days following the first day with average temperature $>14^{\circ} \mathrm{C}$, designated as $\mathrm{DDU}_{30}$, was then calculated. When $\mathrm{DDU}_{30}$ is $\geq 130$, it is assumed that a mosquito that might have taken a blood meal on a microfilaremic host on that particular day, had the possibility of allowing the completion of the extrinsic cycle, hence becoming infective, admitting an average mosquito life span of 30 days $[2,13,40]$, independently of temperatures lower than $14^{\circ} \mathrm{C}$ during that period [41]. With this data, a bar graph was plotted depicting the favourable days for the completion of the extrinsic cycle, and for the transmission of heartworm in the areas and time periods studied [42].

\section{Results}

\section{Mosquito species captured and relative abundance}

In total, 9156 female mosquitoes were caught in the whole sampling period (July/2011-May 2013), representing 11 species from five different genera. Culex (Culex) theileri was the most frequent species (5812, 63.48\%), followed by Cx. (Cux) pipiens s.l. (1940, 21.19\%), Aedes (Ochlerotatus) caspius (601, 6.56\%), Anopheles (Anopheles) maculipennis s.l. (406, 4.43\%), Cx. (Cux) univittatus (145, 1.58\%), Culiseta (Allotheobaldia) longiareolata (30
0.33\%), Ae. (Och) detritus s.l. (23, 0.25\%), Cs. (Culiseta) annulata (17, 0.19\%), An. (Ano) claviger s.l. (4, 0.04\%), Cs. (Cul) subochrea (3, 0.03\%) and Aedes (Och) berlandi (2, $0.02 \%)$. For 143 female mosquitoes it was not possible to identify beyond genus (Culex sp.) and for 30 it was not possible to distinguish between $C x$. theileri and Cx. univittatus, comprising jointly $1.89 \%$ of the total collection.

The district of Santarém showed the highest number of mosquitoes captured $(7818,85.4 \%)$, followed by Coimbra (679, 7.4\%) and Setúbal (659, 7.2\%). Relative frequencies of the mosquito species caught in the different districts are depicted in Figure 1. Culex theileri was the most abundant species in Santarém and Coimbra, followed by $C x$. pipiens s.l. In Setúbal, the most frequent species found were $C x$. pipiens s.l., Cx. theileri, An. maculipennis s.l. and Ae. caspius.

Average mosquito densities, and respective relative frequencies, were estimated according to the collecting method (Figure 2, Table 2). For CDC traps, total mosquito densities differed among the 3 districts (KW: 14.231, $\mathrm{DF}=2, P=0.001$ ) for the joint collections of the sampling period. Santarém exhibited a higher mosquito density compared just to Coimbra.

Culex theileri revealed different densities in the three districts (KW: 8.548, DF=2, $P=0.014$ ), being relatively more abundant just in Santarém compared to Coimbra.

Culex pipiens s.l. equally revealed different densities in the three districts (KW: 19.277, DF $=2, P<0.001$ ), being more abundant in Santarém compared to Coimbra, and to Setúbal.

Aedes caspius also revealed different densities in the three districts (KW: $12.930, \mathrm{DF}=2, P=0.002$ ), being significantly more abundant in Setúbal than in Santarém.

Anopheles maculipennis s.l. collected by CDC traps did not reveal differences among the three surveyed districts.

As for IR collections, these densities also differed among the 3 districts for the total of the collecting period (KW: 9.802, $\mathrm{DF}=2, P=0.007$ ). Mosquito density in Setúbal was significantly higher just in relation to Coimbra.

Culex pipiens s.l. also differed among the 3 districts for the total of the collecting period (KW: 7.230, DF=2, $P=0.027$ ), being more abundant just in Setúbal compared to Coimbra.

Anopheles maculipennis s.l., $C x$. theileri and Ae. caspius were not significantly different between the three districts, in IR collections.

As to mosquito densities on the two surveying years, CDC collections in the second year, 2012/2013: median 22.0 (12.3-50.8) mosquitoes/trap-night, were higher than in the first, 2011/2012: $5.0(0.5-20.5)$ mosquitoes/trapnight (M-W: 1,094.5, $P=0.002)$. This difference was 

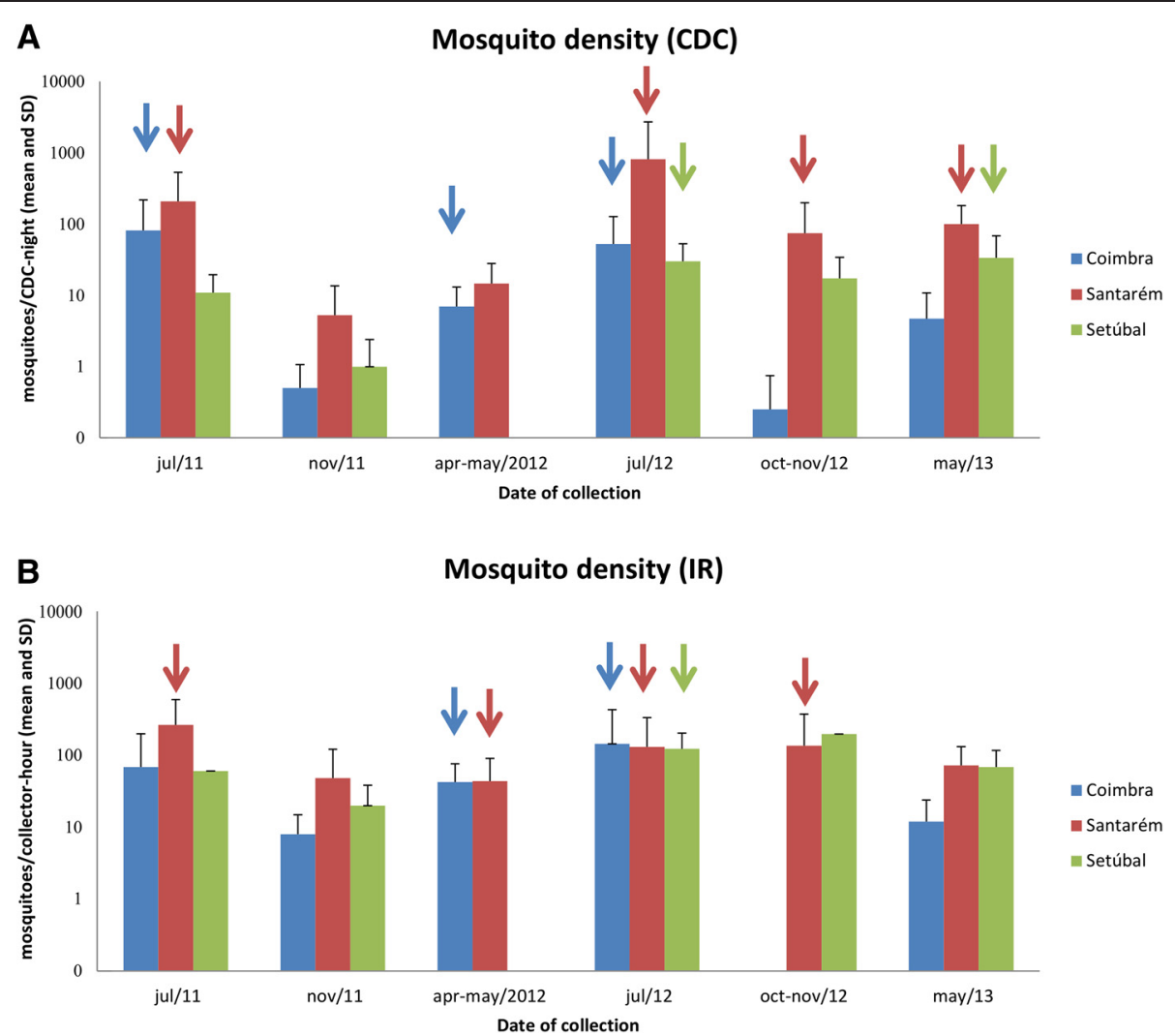

Figure 2 Mosquito average density in the three sampled districts of mainland Portugal, over 2011-2013. A- CDC trap collections; B- Indoor resting (IR) collections; SD - standard deviation. Arrows point to detection of infected mosquitoes.

valid only for Cx. theileri, 2012/2013: 1.5 (0-11.5) mosquitoes/trap-night, compared to 2011/2012: 0.0 (0-1) (M-W: 1,060.0, $P=0.003$ ), and for Cx. pipiens s.l., 2012/ 2013: 12.5 (3-30.5) mosquitoes/trap-night, compared to 2011/2012: 1.0 (0-10.5) mosquitoes/trap-night (M-W:
1,119.0, $P=0.001)$. However, indoor resting collections did not show such differences on the total mosquitoes, but only for Cx. pipiens s.l., 2012/2013: 8.6 (0-48) mosquitoes/collector-hour, compared to 2011/2012: $0.0(0-0.3)$ mosquitoes/collector-hour (M-W: 653.0, $P=0.005)$.

Table 2 Mosquito densities in the three surveyed districts of Portugal, from July 2011 to May 2013

\begin{tabular}{|c|c|c|c|c|c|c|}
\hline \multirow{4}{*}{$\begin{array}{l}\text { Mosquito } \\
\text { species }\end{array}$} & \multicolumn{6}{|l|}{ District } \\
\hline & \multicolumn{2}{|l|}{ Coimbra } & \multicolumn{2}{|l|}{ Santarém } & \multicolumn{2}{|l|}{ Setúbal } \\
\hline & $\overline{C D C}$ & IR & $\mathrm{CDC}$ & IR & $\mathrm{CDC}$ & IR \\
\hline & $\begin{array}{l}\text { mean (SD); median } \\
\text { (Q1-Q3) }\end{array}$ & $\begin{array}{l}\text { mean (SD); median } \\
(\mathrm{Q} 1-\mathrm{Q} 3)\end{array}$ & $\begin{array}{l}\text { mean (SD); median } \\
\text { (Q1-Q3) }\end{array}$ & $\begin{array}{l}\text { mean (SD); median } \\
(\mathrm{Q} 1-\mathrm{Q} 3)\end{array}$ & $\begin{array}{l}\text { mean (SD); median } \\
\text { (Q1-Q3) }\end{array}$ & $\begin{array}{l}\text { mean (SD); median } \\
\text { (Q1-Q3) }\end{array}$ \\
\hline Cx. theileri & $\begin{array}{l}16.3(59.5) ; 0 \\
(0-0)\end{array}$ & $10.9(48.6) ; 0(0-0)$ & $\begin{array}{l}138.4(622.8) ; 1.5 \\
(0-15.3)\end{array}$ & $\begin{array}{l}7.2(21.4) ; 0 \\
(0-6)\end{array}$ & $\begin{array}{l}6.2(12.8) ; 1 \\
(0-4)\end{array}$ & $\begin{array}{l}4.7(9.2) ; 0 \\
(0-6.4)\end{array}$ \\
\hline Cx. pipiens s.l. & $\begin{array}{l}4.8(7.7) ; 0 \\
(0-8)\end{array}$ & $4.4(7.5) ; 0(0-6)$ & $\begin{array}{l}39.2(70.9) ; 15 \\
(5-42.5)\end{array}$ & $\begin{array}{l}26.6(54.7) ; 0 \\
(0-34.7)\end{array}$ & $\begin{array}{l}7.4(8.9) ; 2.5 \\
(0-12.3)\end{array}$ & $\begin{array}{l}51.9(62.8) ; 18 \\
(0-84)\end{array}$ \\
\hline Ae. caspius & $\begin{array}{l}3.5(11.5) ; 0 \\
(0-2)\end{array}$ & $2.1(5.8) ; 0(0-0)$ & $\begin{array}{l}11.9(71.3) ; 0 \\
(0-0)\end{array}$ & $\begin{array}{l}0.3(1.3) ; 0 \\
(0-0)\end{array}$ & $\begin{array}{l}2.8(4.4) ; 1 \\
(0-2.5)\end{array}$ & $\begin{array}{l}2.0(5.5) ; 0 \\
(0-0)\end{array}$ \\
\hline An. maculipennis s.l. & $\begin{array}{l}0.2(0.5) ; 0 \\
(0-0)\end{array}$ & $30.8(117.4) ; 0(0-0)$ & $\begin{array}{l}0.5(1.5) ; 0 \\
(0-0)\end{array}$ & $\begin{array}{l}85.3(187.2) ; 0 \\
(0-30)\end{array}$ & $\begin{array}{l}0.1(0.2) ; 0 \\
(0-0)\end{array}$ & $\begin{array}{l}31.6(69.9) ; 0 \\
(0-30)\end{array}$ \\
\hline Total mosquitoes & $\begin{array}{l}25.2(66.4) ; 3 \\
(0-13.5)\end{array}$ & $\begin{array}{l}48.8(133.9) ; 6 \\
(0-17.8)\end{array}$ & $\begin{array}{l}199.2(759.5) ; 22 \\
(10.5-61)\end{array}$ & $\begin{array}{l}122.5(196.3) ; 42 \\
(0-118.5)\end{array}$ & $\begin{array}{l}17.4(22.5) ; 12 \\
(1.5-20.8)\end{array}$ & $\begin{array}{l}90.8(79.5) ; 72 \\
(27-134.4)\end{array}$ \\
\hline
\end{tabular}

Mean, standard deviation (SD) and medians and interquartile interval (Q1-Q3), of the most abundant species, as well as their total, are presented according to collecting method. CDC: CDC traps, mosquito/trap-night; IR: indoor resting, mosquito/collector-hour. 
Molecular detection of $D$. immitis DNA in mosquitoes

For PCR analysis, we used 5866 adult female mosquitoes. In total, 1815 head+thorax pools and 1529 abdomen pools were screened using the pan-filarial primers. This difference is due to bloodfed or semigravid females that still contained undigested blood in the abdomen, in order to avoid contamination of Dirofilaria spp. DNA that might be in the blood meal, thus preventing assumption of an established mosquito infection. Dirofilaria immitis DNA was found in the four most frequent species, but also in Ae. detritus s.l. (Table 3, with respective values of MIR, ERI and 95\% CI).

Culex pipiens s.l. positive pools for D. immitis, were identified as $C x$. pipiens s.s., 7 form pipiens and 1 form molestus, which was from Setúbal.

The distribution of positive mosquitoes over the three sampled districts, and their respective values of MIR, ERI and 95\% CI are depicted in Table 4.

No amplicons corresponding to the diagnostic size for D. repens DNA were obtained.

Sequencing confirmed all filarial DNA as belonging to $D$. immitis (nucleotide sequence data are available under accession numbers [ENA: LN626262 to LN626267] [43], with a sequence similarity on BLAST [36] that ranges from $89 \%$ to $97 \%$ with sequences available at NCBI database [JX866681.1; DQO18785.1; JX866681.1; FJ263464.1; FJ2634571; HM126606.1.].

Overall, mosquitoes with $D$. immitis DNA were found in all collecting dates, but November 2011, usually by both methods and in more than one district (Figure 2, Table 5).

The overall infection rate of mosquitoes was significantly different for the three districts $\left(\chi^{2}=40.93, \mathrm{Df}=2\right.$, $P<0.0001)$, being higher in Coimbra $(3.21 \%)$, compared to Santarém $\left(0.54 \%, \chi^{2}=36.11, \mathrm{Df}=2, P<0.0001\right)$ or Setúbal $\left(1.22 \%, X^{2}=19.46, \mathrm{Df}=2, P<0.0001\right)$, but not significantly different between Santarém and Setúbal.

\section{Estimation of transmission risk of Dirofilaria spp. by mosquitoes}

The calculation of the $\mathrm{DDU}_{30}$ for the three studied districts showed that there was, at least, 152 days in 2011, 119 days in 2012 and 117 days in 2013 with suitable conditions for the completion of the extrinsic development of Dirofilaria spp., and consequently, for its transmission to the vertebrate host (Figure 3). Most of the infected mosquito pools detected in this work (red lines) are in agreement with the determined favourable development periods.

\section{Discussion}

To our knowledge, this is the first report of molecular evidence for natural infections of mosquitoes with $D$. immitis in continental Portugal. Despite known prevalence of canine dirofilariasis (CD), the knowledge of its natural and potential vectors in mainland Portugal was scarce, with a historical study considering $C x$. theileri as a probable vector of Dirofilaria spp. [25]. We report the finding of $A n$. maculipennis s.l., Ae. caspius, Ae. detritus s.l. and $C x$. theileri as likely competent vectors of $D$. immitis, i.e. with DNA in head+thorax, and Cx. pipiens form pipiens and form molestus, as likely vectors, i.e.with DNA only in abdomens, but from mosquitoes without any traces of bloodmeal. In this work, only D. immitis was detected, in contrast with recent findings of $D$. repens in other Southern European countries such as Italy, albeit in much lower rates than D. immitis, in $C x$. pipiens [16,17], or at similar rates as $D$. immitis in Cx. pipiens and Ae. albopictus [44]. On the other hand, this is not surprising as D. repens was not found in parallel animal surveys in the same districts of Portugal [24].

Culex theileri, Cx. pipiens s.l. and An. maculipennis s.l. have already been implicated as vectors in countries such as Spain [15,20], Italy [16,17], Turkey [18] and Iran

Table 3 Dirofilaria immitis DNA detected in mosquitoes collected in Portugal, 2011-2013

\begin{tabular}{|c|c|c|c|c|c|c|c|c|c|}
\hline \multirow[t]{2}{*}{ Mosquito species } & \multirow{2}{*}{$\begin{array}{l}\text { Mosquitoes } \\
\text { collected }\end{array}$} & \multicolumn{2}{|c|}{ Mosquitoes tested } & \multicolumn{2}{|l|}{ Positive PCR } & \multirow{2}{*}{$\begin{array}{l}\text { Number } \\
\text { of } \\
\text { positive } \\
\text { pools }^{\S}\end{array}$} & \multirow[t]{2}{*}{ MIR } & \multirow[t]{2}{*}{ ERI } & \multirow[t]{2}{*}{$95 \% \mathrm{Cl}$} \\
\hline & & Specimens & Poolst & Head+thorax & Abdomen & & & & \\
\hline Cx. theileri & 5812 & 3406 & 234 & 13 & 16 & 23 & $6.8 / 1000$ & $0.71 \%$ & $0.005-0.01$ \\
\hline Cx. pipiens s.l. & 1940 & 1595 & 1123 & 0 & 8 & 8 & $5 / 1000$ & $0.50 \%$ & $0.003-0.01$ \\
\hline Ae. caspius & 601 & 270 & 193 & 4 & 8 & 10 & $37 / 1000$ & $3.73 \%$ & $0.02-0.067$ \\
\hline An. maculipennis s.l. & 406 & 400 & 114 & 5 & 8 & 12 & $30 / 1000$ & $3.12 \%$ & $0.017-0.052$ \\
\hline Ae. detritus s.l. & 23 & 23 & 16 & 1 & 1 & 1 & $43.5 / 1000$ & $4.39 \%$ & $0.008-0.21$ \\
\hline Other species* & 374 & 172 & 135 & 0 & 0 & 0 & - & - & \\
\hline TOTAL & 9156 & 5866 & 1815 & 0 & 0 & 0 & $9.2 / 1000$ & $0.91 \%$ & $0.007-0.012$ \\
\hline
\end{tabular}

$\S$ - whether in just one portion of the body or both; ${ }^{*}$ - other species and unidentifiable mosquitoes; $\uparrow-$ includes individual specimens as well. 
Table 4 Dirofilaria immitis infection of mosquitoes by sampling districts of Portugal, 2011-2013

\begin{tabular}{|c|c|c|c|c|c|c|c|c|c|}
\hline \multirow[t]{2}{*}{ Districts } & \multirow{2}{*}{$\begin{array}{l}\text { Mosquitoes } \\
\text { collected }\end{array}$} & \multicolumn{2}{|c|}{ Mosquitoes tested } & \multicolumn{2}{|l|}{ Positive PCR } & \multirow{2}{*}{$\begin{array}{l}\text { Number } \\
\text { of } \\
\text { positive } \\
\text { pools }\end{array}$} & \multirow[t]{2}{*}{ MIR } & \multirow[t]{2}{*}{ ERI } & \multirow[t]{2}{*}{$95 \% \mathrm{Cl}$} \\
\hline & & Specimens & Poolst & Head+thorax & Abdomen & & & & \\
\hline Coimbra & 679 & 678 & 209 & 9 & 14 & 21 & $31.0 / 1000$ & $3.21 \%$ & $0.02-0.047$ \\
\hline Santarém & 7818 & 4530 & 1208 & 13 & 19 & 25 & $5.5 / 1000$ & $0.54 \%$ & $0.004-0.008$ \\
\hline Setúbal & 659 & 658 & 398 & 1 & 8 & 8 & $12.2 / 1000$ & $1.22 \%$ & $0.006-0.024$ \\
\hline TOTAL & 9156 & 5866 & 1815 & 23 & 41 & 54 & $9.2 / 1000$ & $0.91 \%$ & $0.007-0.012$ \\
\hline
\end{tabular}

$\S$ - whether in just one portion of the body or both; $\uparrow-$ includes individual specimens as well.

[21]. Aedes caspius and Ae. detritus s.l. are here for the first time, to the best of our knowledge, implicated as natural competent vectors of $D$. immitis. Aedes caspius had been found positive for the whole mosquito [17], and Ae. detritus s.l. for the abdominal portion [45], hence requiring confirmation. This is also the first study in which both biological forms of $C x$. pipiens s.s., form pipiens and form molestus have been found infected with D. immitis. In Portugal, there are to date, records of $C x$. pipiens and $C x$. torrentium as members of the $C x$. pipiens complex [46]. Culex torrentium is rare and occurs only in northern and mountain areas of the country [46], therefore, none of the collected specimens could belong to this species. As to Culex quinquefasciatus, although it has not yet been recorded in Portugal, hybrids with $C x$. pipiens have recently been found in Greece [47]. For this reason, and considering either the ongoing climatic changes and its consequences on species distribution, or the similar PCR results between form molestus of $C x$. pipiens s.s. and $C x$. quinquefasciatus, all specimens were treated as $C x$. pipiens s.l.; the molecular identification being made only for positive specimens for D. immitis.

Anopheles maculipennis s.l. has also been previously found infected with D. immitis [16]. However, An. atroparvus is the only member of this complex occurring south of the Montejunto-Estrela mountain range, and even to the north of this range a proportion of nine $A n$. atroparvus to one An. maculipennis s.s. was found $[46,48,49]$. Thus, we can be confident that the positive An. maculipennis s.l. in the district of Setúbal are in fact
An. atroparvus, hence becoming the first vector incrimination for this species.

Aedes detritus s.l. were not differentiated as the technique available at the time of this study would preclude the screening for dirofilarial DNA.

Infection rates were similar whether estimated as MIR or ERI, probably as a great proportion of our pools were of a single mosquito specimen. The species with the highest infection rates were Ae. caspius (3.7\%), followed by An. maculipennis s.l. (3.1\%), Cx. theileri (0.7\%) and Cx. pipiens s.l. (0.5\%). The highest infection rate was in fact recorded for Ae. detritus s.l.. However, infection rates based on small sample sizes, i.e. $<1000$, may not accurately represent the true infection rate in the population [50]. Whereas in the case of An. maculipennis s.l. and Ae. caspius the sample size is 400 and 270, respectively, with somewhat large $95 \%$ CIs, and therefore, infection rates should be interpreted with caution, in the case of Ae. detritus s.l., with a sample of 23 specimens and a much wider $95 \% \mathrm{CI}$, the very high infection rate has a reduced significance.

Infection of $C x$. pipiens in Spain has been detected with a rate of $0.3 \%$ [15], in Italy it ranges from $0.048 \%$ [17], much lower than this present study, to $0.26 \%$ and $0.54 \%[16,44]$, similar to our values, with an intermediate prevalence rate in Turkey of $0.12 \%$ [18]. Infection rates in Ae. caspius in Italy were much lower than ours, $0.18 \%$ [17]. Still in Italy, 5.26\% (1/19) of An. maculipennis s.l. were found infected. However, much higher infection rates for An. maculipennis, $11.7 \%$ (4/34) and Cx. theileri, $10 \%(15 / 149)$ were found in Iran [21],

Table 5 Occurrence of mosquitoes positive for D. immitis, according to species, district and date, Portugal 2011-2013

\begin{tabular}{|c|c|c|c|c|c|c|}
\hline \multirow[t]{2}{*}{ Mosquito species } & \multicolumn{2}{|l|}{2011} & \multicolumn{3}{|l|}{2012} & \multirow{2}{*}{$\begin{array}{l}2013 \\
\text { MAY }\end{array}$} \\
\hline & JUL & NOV & APR-MAY & JUL & OCT-NOV & \\
\hline Cx. theileri & $\mathrm{CO}, \mathrm{SA}$ & - & - & $\mathrm{CO}, \mathrm{SA}, \mathrm{SE}$ & SA & SE \\
\hline Cx. pipiens s.s. & $\mathrm{CO}, \mathrm{SA}$ & - & - & SA & - & SA, SE \\
\hline Ae. caspius & $\mathrm{CO}, \mathrm{SA}$ & - & $\mathrm{CO}$ & $\mathrm{CO}$ & - & SE \\
\hline An. maculipennis s.l. & SA & - & $\mathrm{CO}, \mathrm{SA}$ & $\mathrm{CO}, \mathrm{SA}, \mathrm{SE}$ & SA & - \\
\hline Ae. detritus s.l. & - & - & $\mathrm{CO}$ & - & - & - \\
\hline
\end{tabular}

CO, Coimbra; SA, Santarém; SE, Setúbal. 


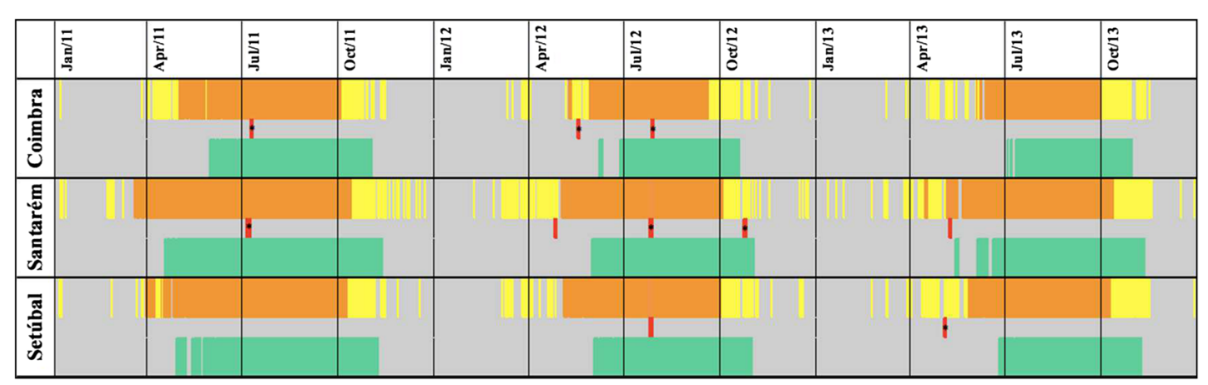

Figure 3 Potential transmission period of Dirofilaria spp. in 2011-2013 for Coimbra, Santarém and Setúbal, Portugal. Yellow-days with average temperature above $14^{\circ} \mathrm{C}$; Orange-Days with average temperature above $14^{\circ} \mathrm{C}$ and at least $130 \mathrm{DDU}_{30}$; Green-days with transmission risk to the vertebrate host, 30 days after the first day with $130 \mathrm{DDU}_{30}$; Red bars indicate the occurrence of positive mosquito pools in this work, abdomen pools, when plain, and head+thorax pools, when marked with a black star.

albeit several of these values were based on small sample sizes.

In Portugal, previous detection of Dirofilaria spp. L1 and L2 larvae in the MT of $C x$. theileri, in the district of Setúbal, had yielded an infection rate of $4.76 \%$, again, in a small sample $(\mathrm{N}=42)$ [25]. In islands of Macaronesia, $C x$. theileri has been found at infection rates of $0.16 \%$ in the Canaries [20] and circa $0.9 \%-1.13 \%$ in Madeira [19], to which the values in this study are more approximate.

In continental Portugal there are 41 identified species of mosquitoes [46], however, An. maculipennis s.l., Cx. pipiens s.l., Cx. theileri and Ae. caspius are the most abundant and broadly distributed [26]. In the three districts surveyed in this work, these were also the species with highest densities. Total mosquito densities were lower in Coimbra, the northern most district, in agreement with previous surveys, namely for $C x$. pipiens s.l., by both methods, as a sign of identical capture yield for this species [26]. Conversely, CDC trap catches were able to show different densities among districts, for $C x$. theileri and Ae. caspius, as they are superior for targeting these species [26]. On the other hand, IR catches yielded higher numbers of An. maculipennis s.l., as IR tends to be a more adequate method to capture this species [51]. Nevertheless, in this study, a striking difference was reported in the mosquito abundance in the district of Setúbal, with much lower densities compared to previous works $[26,52,53]$. The reasons contributing to this may well be i) the location of the collecting sites close to kennels, as per the experimental design, and which in this district were in areas not favourable for mosquito breeding, as opposed to earlier works which included rice fields and wetlands; ii) relatively low number of collections, with only one set in peak breeding season; and iii) strong winds registered in some of the collecting dates, as noted in field collection registers.

Collections in the second year yielded higher densities, particularly for $C x$. theileri and $C x$. pipiens s.l.. This increase may be due to local environmental variables, particularly climatic. Although no significant differences were registered for the average temperatures, precipitation was higher in the three districts in the second sampling year, 2012/2013. Nevertheless, considering there were only three collecting moments per year, there is not enough data to draw conclusions on the seasonal dynamics of mosquitoes.

Infection rates in mosquitoes were not in agreement with prevalence rates of $\mathrm{CD}$ found in the same research project [24], despite having targeted mosquito collections to the vicinity of kennels. Highest and lowest infection rates for mosquitoes were registered in Coimbra and Santarém, respectively, which had similar prevalence rates of $\mathrm{CD}$. On the other hand, Setúbal, which had the highest $\mathrm{CD}$ prevalence rate, registered an intermediate mosquito infection rate. There are many factors whose influence is still unknown (vector efficiency of each species, overall level of protection in the dog population by preventive therapy, local environmental conditions in studied areas, etc.).

During the two year survey, infected mosquitoes were found in five of the six collection dates, representing an almost continuous presence of infected vectors, particularly in Santarém. Furthermore, infected mosquitoes were found by both methods in most of the collecting dates and sites. It can be argued that infected mosquitoes in IR collections may have become infected in the hosts in the shelters, however, the CDC trap collected mosquitoes represent the mosquito population searching for hosts and are proof therefore of circulating infected vectors. Coimbra was the only district with the five infected species as Ae. detritus s.l. was only found infected there, while Santarém and Setúbal registered four infected species.

The calculation of the $\mathrm{DDU}_{30}$ ranged from 117 days in 2013 to 152 days in 2011 with favourable temperatures for the completion of the extrinsic cycle of $D$. immitis, hence the existence of infective mosquito vectors that would complete the transmission cycle. Most of the 
infective and infected mosquitoes detected were collected during these favourable periods. The few exceptions are probably due to their maintenance in the insectary for the seven day period, which proves highly important in such studies. Although a 7 day period at $25^{\circ} \mathrm{C}$ may not be enough for the completion of the extrinsic cycle, a compromise had to be taken to compensate for mosquito mortality and filarial DNA degradation, while allowing for complete digestion of bloodmeals.

Activity of these mosquitoes, whether infected, infective or neither, was found in the three time point collections, corresponding to Spring, Summer and Autumn. In the context of climate changes, particularly in Portugal, where temperature increases have reached $0.5^{\circ} \mathrm{C} /$ decade since 1970, more than twice higher than the global median temperature [54], and with future scenarios that may range between $3-5.8^{\circ} \mathrm{C}$ by $2040-2090$, the activity period for mosquitoes, and hence mosquito-borne diseases are likely to increase [55]. This is further relevant as dirofilariasis is recognized as an expanding zoonosis, particularly in Europe $[4,5]$. Our results are in agreement with predictions of occurrence and seasonality of Dirofilaria spp., with peaks of infection in Summer, from June to September, even in countries of Northern Europe [2,13,14,42].

\section{Conclusions}

We have confirmed and reported new mosquito vectors of dirofilariasis in three districts of Portugal with high prevalence of $\mathrm{CD}$. To our knowledge, the present study is the first PCR screening for Dirofilaria spp. in mosquitoes for continental Portugal. Our results confirm that not only $C x$. theileri is capable of becoming infected with $D$. immitis, but also Ae. caspius, An. maculipennis s.l., An. atroparvus, $C x$. pipiens of both bioforms pipiens and molestus and Ae. detritus s.l. can support the development of D. immitis, and with the exception of $C x$. pipiens, to the L3 infective stage, based on the presence of filarial DNA in the head+thorax. Most of these results were in agreement with the prediction of $130 \mathrm{DDU}_{30}$ for the regions surveyed. The finding of infected and infective mosquitoes in the three districts and in the SpringAutumn interval heightens the necessity for prophylactic protective measures to prevent transmission at least during this period. Further studies are necessary to ascertain whether transmission season is wider than the interval Spring-Autumn.

\section{Competing interests}

The authors declare that they have no competing interests.

\section{Authors' contributions}

SB and APGA conceived the study, its design and coordination. APGA, MTN CF, MC and SB participated in field work. APGA, MTN and VM identified the mosquitoes. CF and VM carried out the molecular studies, sequence alignment and drafted the manuscript. MC participated in the molecular studies and sequence alignment. LG supervised the statistical analysis. VM and CF analyzed the data. APGA supervised the analysis of the data and reformulated the manuscript. All authors read and approved the final manuscript.

\section{Acknowledgments}

The authors thank all veterinarians and staff from municipal kennels for the collaboration. Prof. Luís Madeira de Carvalho, Faculdade de Medicina Veterinária, Portugal - for providing D. immitis, Profa Eva Fok, Faculty of Veterinary, Szent Istvan University, Hungary - for providing D. repens, adult worms, and Prof. João Pinto, Instituto de Higiene e Medicina Tropical, Portugal - for providing $C$ x. pipiens f. pipiens, $C$ x. pipiens f. molestus and $C X$. quinquefasciatus DNA. We are grateful to Jolyon Medlock for the kind revision of English and valuable comments. This study was financed by Fundação para a Ciência e Tecnologia, project grant PTDC/SAU-SAP/113523/2009 and UPMM - PEst-OE/SAU/UI0074/2011-2014

\section{Author details}

${ }^{1}$ Medical Parasitology Unit, Medical Parasitology \& Microbiology Unit-UPMM, Instituto de Higiene e Medicina Tropical, Universidade Nova de Lisboa, Rua da Junqueira 100, 1349-008 Lisboa, Portugal. '2Zoonosis Research Unit, Faculty of Health Sciences, University of Pretoria, Pretoria, South Africa. ${ }^{3}$ International Public Health and Biostatistics Unit, Instituto de Higiene e Medicina Tropical, Universidade Nova de Lisboa, Rua da Junqueira 100, 1349-008 Lisboa, Portugal. ${ }^{4}$ Centro de Estatística e Aplicações da Universidade de Lisboa, Faculdade de Ciências da Universidade de Lisboa, Bloco C6 - Piso 4, Campo Grande 1749-016 Lisboa, Portugal.

Received: 29 October 2014 Accepted: 20 February 2015

Published online: 03 March 2015

\section{References}

1. Anderson RC. Nematode parasites of vertebrates. Their development and transmission. Wallingford: CABI Publishing; 2000.

2. Genchi C, Rinaldi L, Cascone C, Mortarino M, Cringoli G. Is heartworm really spreading in Europe? Vet Parasitol. 2005;133:137-48.

3. McCall JW, Genchi C, Kramer LH, Guerrero J, Venco L. Heartworm disease in animals and humans. AdvParasitol. 2008;66:193-285.

4. Traversa D, Cesare A, Conboy G. Canine and feline cardiopulmonary parasitic nematodes in Europe: emerging and underestimated. Parasites Vectors. 2010:3:62.

5. Simón F, Siles-Lucas M, Morchón R, González-Miguel J, Mellado I, Carretón E, et al. Human and animal dirofilariasis: the emergence of a zoonotic mosaic. ClinMicrobiol Rev. 2012;25:507-44

6. Miterpáková M, Antolová D, Hurníková Z, Dubinský P, Pavlacka A, Németh J. Dirofilaria infections in working dogs in Slovakia. J Helminthol. 2010;84:173-6. doi: 10.1017/S0022149X09990496.

7. Jacso O, Mandoki M, Majoros G, Petsch M, Mortarino M, Genchi C, et al. First autochthonous Dirofilaria immitis (Leidy, 1856) infection in a dog in Hungary. Helminthologia. 2009;46:159-61.

8. Świątalska A, Demiaszkiewicz AW. First autochthonous case of Dirofilaria immitis invasion in dog in Poland. ŽycieWeterynaryjne. 2012;87:685.

9. Szénási Z, Kovács AH, Pampiglione S, Fioravanti ML, Kucsera I, Tánczos B, et al. Human dirofilariosis in Hungary:an emerging zoonosis in central Europe. Wien KlinWochenschr. 2008;120:96-102.

10. Cielecka D, Zarnowska-Prymek H, Masny A, Salamatin R, Wesolowska M, Golab E. Human dirofilariosis in Poland: the first cases of autochthonous infections with Dirofilaria repens. Ann AgricEnviron Med. 2012;19:445-50.

11. Sałamatin RV, Pavlikovska TM, Sagach OS, Nikolayenko SM, Kornyushin W, Kharchenko VO, et al. Human dirofilariasis due to Dirofilaria repens in Ukraine, an emergent zoonosis: epidemiological report of 1465 cases. Acta Parasitol. 2013;58:592-8.

12. Tasić-Otašević SA, Gabrielli SV, Tasić AV, Miladinovićtasić NL, Kostić JT, Ignjatović AM, et al. Seroreactivity to Dirofilaria antigens in people from different areas of Serbia. BMC Infect Dis. 2014;14:68.

13. Genchi C, Rinaldi L, Mortarino M, Genchi M, Cringoli G. Climate and Dirofilaria infection in Europe. Vet Parasitol. 2009;163:286-92.

14. Medlock LM, Barras I, Kerrod E, Taylor MA, Leach S. Analysis of climatic predictions for extrinsic incubation of Dirofilaria in the United Kingdom. Vector Borne Zoon Dis. 2007;7:4-14 
15. Morchón R, Bargues MD, Latorre JM, Melero-Alcíbar R, Pou-Barreto C, Mas-Coma $\mathrm{S}$, et al. Haplotype $\mathrm{H} 1$ of Culex pipiens implicated as a natural vector of Dirofilaria immitis in an endemic area of western Spain. Vector Borne Zoon Dis. 2007;7:653-8.

16. Cancrini G, Magi M, Gabrielli S, Arispici M, Tolari F, Dell'Omodarme M, et al. Natural vectors of dirofilariasis in rural and urban areas of the Tuscan region, central Italy. J Med Entomol. 2006;43:574-9.

17. Latrofa MS, Montarsi F, Ciocchetta S, Annoscia G, Dantas-Torres F, Ravagnan $S$, et al. Molecular xenomonitoring of Dirofilaria immitis and Dirofilaria repens in mosquitoes from north-eastern Italy by real-time PCR coupled with melting curve analysis. Parasites Vectors. 2012;5:76.

18. Yildirim A, Inci A, Duzlu O, Biskin Z, Ica A, Sahin I. Aedesvexans and Culex pipiens as potential vectors of Dirofilaria immitis in Central Turkey. Vet Parasitol. 2011;178:143-7

19. Santa-Ana M, Khadem M, Capela R. Natural infection of Culex theileri (Diptera, Culicidae) with Dirofilaria immitis (Nematoda, Filarioidea) on Madeira Island, Portugal. J Med Entomol. 2006:43:104-6.

20. Morchón R, Bargues MD, Latorre-Estivalis JM, Pou-Barreto C, Melero-Alcibar $\mathrm{R}$, Moreno M, et al. Molecular Characterization of Culex theileri from Canary Islands, Spain, a potential vector of Dirofilaria immitis. J Clinic Experiment Pathol. 2011;\$3:001. doi:10.4172/2161-0681.S3-001.

21. Azari-Hamidian S, Yaghoobi-Ershadi MR, Javadian E, Abai MR, Mobedi I, Linton YM, et al. Distribution and ecology of mosquitoes in a focus of in northwestern Iran, with the first finding of filarial larvae in naturally infected local mosquitoes. Med Vet Entomol. 2009;23:111-21.

22. Cancrini G, Ricci I, Tessarin C, Gabrielli S, Pietrobelli M. Aedesalbopictus is a natural vector of Dirofilaria immitis in Italy. Vet Parasitol. 2003;188:195-202.

23. Vieira L, Silvestre-Ferreira AC, Fontes-Sousa AP, Balreira AC, Morchón R, Carretón E, et al. Seroprevalence of heartworm (Dirofilaria immitis) in feline and canine hosts from central and northern Portugal. JournHelminth. 2014;14:1-5.

24. Alho AM, Landum M, Ferreira C, Meireles J, Gonçalves L, Madeira de Carvalho $L$ etal. Prevalence and seasonal variations of canine dirofilariosis in Portugal. Vet Parasitol 2014, doi:10.1016/j.vetpar.2014.08.014.

25. Ribeiro H, Ramos HC, Pires CA. Contribuição para o estudo dos vectores de filaríases animais em Portugal. J Socied Ciências Médicas. 1983:147:143-6.

26. Almeida APG, Galão RP, Sousa CA, Novo MT, Parreira R, Pinto J, et al. Potential mosquito vectors of arboviruses in Portugal: species, distribution, abundance and West Nile infection. Transact Royal Soc Trop Med Hygiene. 2008;102:823-32

27. Instituto Português do Mar e da Atmosfera https://www.ipma.pt/.

28. Ribeiro H, Ramos HC. Identification keys of the mosquitoes of continental Portugal, Azores and Madeira. Eur Mosquito Bull. 1999:3:1-11.

29. Favia G, Lanfrancotti A, Della Torre A, Cancrini G, Coluzzi M. Polymerase chain reaction identification of Dirofilaria repens and Dirofilaria immitis. Parasitology. 1996;6:567-71

30. Gomes B, Sousa C, Novo M, Freitas FB, Alves R, Côrte-Real AR, et al. Asymmetric introgression between sympatric molestus and pipiens forms of Culex pipiens (Diptera: Culicidae) in the Comporta region. Portugal BMC EvoBiol. 2009;9:262

31. Stothard JR, Hughes S, Rollinson D. Variation within the Internal Transcribed Spacer (ITS) of ribosomal DNA genes of intermediate snail hosts within the genus Bulinus (Gastropoda: Planorbidae). Acta Trop. 1996;61:19-29.

32. Rishniw M, Barr SC, Simpson KW, Frongillo MF, Franz M, Dominguez Alpizar J. Discrimination between six species of canine microfilariae by a single polymerase chain reaction. Vet Parasitol. 2006;135:303-14.

33. Bahnck CM, Fonseca DM. Rapid assay to identify the two genetic forms of Culex (Culex) pipiens L. (Diptera: Culicidae) and hybrid populations. Amer J Trop Med Hygiene. 2006;75:251-5

34. Smith JL, Fonseca DM. Rapid assays for identification of members of the Culex (Culex) pipiens complex, their hybrids, and other sibling species (Diptera: culicidae). Amer J Trop Med Hygiene. 2004;70:339-45.

35. Hall TA. BioEdit: a user-friendly biological sequence alignment editor and analysis program for Windows 95/98/NT. Nucl Acids SympSer. 1999:41:95-8.

36. BLAST ${ }^{\oplus}$ Basic Local Alignment Search Tool. http://blast.ncbi.nlm.nih.gov/ Blast.cgi.

37. Cowling DW, Gardner IA, Johnson WO. Comparison of methods for estimation of individual-level prevalence based on pooled samples. Prev Vet Med. 1999;39:211-25.

38. SPSS for Windows ${ }^{\circledR}$ Inc., Statistical Package for Social Sciences ${ }^{\oplus}$, IBM Chicago, Illinois, USA. 1999
39. Siegel S, Castellan Jr NJ. Nonparametric Statistics for the Behavioral Sciences. New York: McGraw-Hill; 1988.

40. Fortin JF, Slocombe JOD. Temperature requirements for the development of Dirofilaria immitis in Aedes triseriatus and Ae. vexans. Mosq News. 1981;41:625-33.

41. Venco L, Genchi M, Genchi C, Gatti D, Kramer L: Can heartworm prevalence in dogs be used as provisional data for assessing the prevalence of the infection in cats? Vet Parasitol. 2011, 22;176:300-3. doi: 10.1016/j. vetpar.2011.01.013

42. Sassnau R, Czajka C, Kronefeld M, Werner D, Genchi C, Tannich E, Kampen H: Dirofilaria repens and Dirofilaria immitis DNA findings in mosquitoes in Germany: temperature data allow autochthonous extrinsic development. Parasitol Res 2014, doi 10.1007/s00436-014-3970-1.

43. ENA 'European Nucleotide Archive' http://www.ebi.ac.uk/ena/data/view/ LN626257-LN626267. accessed March/April 2015.

44. Cancrini G, Scaramozzino P, Gabrielli S, di Paolo M, Toma L, Romi R. Aedes albopictus and Culex pipiens implicated as natural vectors of Dirofilaria repens in central Italy. J Med Entomol. 2007;44:1064-6.

45. Cancrini G, Gabrielli S. Vectors of Dirofilaria nematodes: biology, behaviour and host/parasite relationships. In: Genchi C, Rinaldi L, Cringoli G, editors. Dirofilariaimmitis and D. repens in dog and cat and human infection. Naples: Rolando editore; 2007. p. 49-58.

46. Ribeiro H, Ramos HC, Pires CA, Capela RA. An annotated checklist of the mosquitoes of continental Portugal (Diptera, Culicidae). Actas do III Congresso Ibérico de Entomologia [Proceedings of the III Iberian Congress of Entomology], 1988, 233-254.

47. Shaikevich E, Vinogradova E. The discovery of a hybrid population of mosquitoes of the Culex pipiens L. complex (Diptera, Culicidae) on the Kos Island (Greece) by means of molecular markers. Entomologicheskoe Obozrenie. 2013;92(3):480-5. English version in Entomological Review 2014,94: 35-39 doi:10.1134/S0013873814010047.

48. Sousa CA. Malaria vectorial capacity and competence of Anopheles atroparvus Van Thiel, 1927 (Diptera: Culicidae): Implications for the potential re-emergence of malaria in Portugal. PhD Thesis. Lisboa, Portugal: Universidade Nova de Lisboa, Instituto de Higiene e Medicina Tropical; 2008.

49. Capinha C, Gomes E, Reis E, Rocha J, Sousa CA, Do Rosário VE, et al. Present habitat suitability for Anopheles atroparvus (Diptera, Culicidae) and its coincidence with former malaria areas in Mainland Portugal. Geospatial health. 2009;3:177-87.

50. Walter SD, Hildreth SW, Beaty BJ. Estimation of infection rates in population of organisms using pools of variable size. Am J Epidemiol. 1980:112:124-8

51. Lourenço PM, Sousa CA, Seixas J, Lopes P, Novo MT, Almeida AP. Anopheles atroparvus density modeling using MODIS NDVI in a former malarious area in Portugal. J Vector Ecol. 2011;36:279-91.

52. Almeida APG, Freitas FB, Novo MT, Sousa CA, Rodrigues JC, Alves R, et al Mosquito surveys and West Nile virus screening in two different areas of Southern Portugal, 2004-2007. Vector Borne Zoon Dis. 2010;10:673-80.

53. Osório HC, Amaro F, Zé-Zé L, Moita S, Labuda M, Alves MJ. Species composition and dynamics of adult mosquitoes of Southern Portugal. Eur Mosquito Bull. 2008;25:12-23.

54. Ramos AM, Trigo RM, Santo FE. Evolution of extreme temperatures over Portugal: recent changes and future scenarios. Clim Res. 2011;48:177-92.

55. Casimiro E, Calheiros J, Santos FD, Kovats S. National assessment of human health effects of climate change in Portugal: approach and key findings. Environ Health Perspect. 2006;114:1950-6.

\section{Submit your next manuscript to BioMed Central and take full advantage of:}

- Convenient online submission

- Thorough peer review

- No space constraints or color figure charges

- Immediate publication on acceptance

- Inclusion in PubMed, CAS, Scopus and Google Scholar

- Research which is freely available for redistribution 